\title{
Testing the effectiveness of release valves under intensive dynamic load to the leg
}

\author{
Stanistaw SZWEDA ${ }^{1 *}$, Wtodzimierz MADEJCZYK ${ }^{2}$ and Jarostaw CZUBASZEK ${ }^{3}$
}

\author{
Authors' affiliations and addresses: \\ ${ }^{1}$ KOMAG Institute of Mining Technology, \\ The Advisory Team, Pszczyńska 37, \\ 44-101 Gliwice, Poland \\ e-mail: sszweda@komag.eu \\ ${ }^{2}$ KOMAG Institute of Mining Technology, \\ Laboratory of Tests, Pszczyńska 37, \\ 44-101 Gliwice, Poland \\ e-mail: wiemad@wp.pl
}

${ }^{3}$ KOMAG Institute of Mining Technology, Laboratory of Tests, Pszczyńska 37,

44-101 Gliwice, Poland

e-mail: jczubaszek@komag.eu

\section{*Correspondence:}

Stanisław Szweda, KOMAG Institute of Mining Technology, Pszczyńska 37, 44-101 Gliwice,

Poland

tel.: +48 512304029

e-mail: sszweda@komag.eu

\section{Acknowledgement:}

This article is based on the results of own tests financed by KOMAG

\section{How to cite this article:}

Szweda, S., Madejczyk, W. and Czubaszek, J. (2020). Testing the effectiveness of release valves under intensive dynamic load to the leg. Acta Montanistica Slovaca, Volume 25 (4), 466-478

DOI:

https://doi.org/10.46544/AMS.v25i4.03

\begin{abstract}
Release valves are commonly used to protect hydraulic legs against overload caused by rock bursts or bumps. Due to an essential role in ensuring safety in the working, an application of a release valve is conditioned by a positive yield test results of a leg equipped with such a valve. A method of leg yield testing, used in Poland, enables a complex determination of an impact of not only a release valve but also of the parameters of the hydraulic leg, determining its stiffness such as for example a volume of the under-the-piston space, which has an impact on an observed pressure increase.

The subject of this publication covers cognitive tests oriented onto a determination of an impact of a release valve exclusively on the pressure changes observed in the leg. The results of the efficiency tests of spring valves (Stoiński, 2018) on a rammer are discussed. The difference between the maximum pressure in the under-piston area of the leg with the release valve and the maximum pressure generated by the same dynamic load in the leg without this valve was the measure of the valve operation's effectiveness.

Dynamic load, realized on a rammer, is characterized by a longer increase time than in the case of dynamic load acting on a powered roof support unit from the floor. The time process of the force in the leg is then characterized by a short load rising time $-t_{n}$, large load increment factor $-K_{d}$ and the average load growth rate $-w_{p, n}$. Referring to that aspect, the features of a release valve were analyzed in relation to the parameters characterizing dynamic load acting on a powered roof support unit from the floor.

Parameters characterizing the effectiveness of the release valve, i.e. change in the leg load increment index $-\Delta K_{d}$ and change in the rate of load increase $-\Delta w_{p n}$ were defined. The test stand for generating the load of such parameters using the explosive method is described. Comparison of effects of the dynamic load generated by firing the same mass and the same type of explosive on a hydraulic leg with a release valve and the leg without this valve was the test objective.

The effectiveness of the spring valve and two gas valves are analyzed. It was found that despite a very short load rising time, the release valve reduces the load acting on the leg. The positive values of the $\Delta K_{d}$ and $\Delta w_{p, n}$ indices are the evidence.
\end{abstract}

\section{Keywords}

Release valve, laboratory test, floor bump, explosives. 


\section{Introduction}

Dynamic phenomena such as rock bursts and bumps are still a big safety hazard in exploitation workings. In 2018 , the production from the zones where bumping hazards occur reached about $54 \%$ of the total production rates (Kabiesz, 2019). According to Świątek (2020), it can be assumed that in $60 \%$ of seams, under mining, hazards of high energy bursts occur. Installation of an additional release valve in the leg's hydraulic system is a commonly used method for protecting legs against overload. In this way, the leg's yielding capacity is increased. Leg's yielding capacity is assessed by tests at dynamic load (Stoiński, 2018). Proper selection of parameters of the valve protecting the given leg is an important aspect of this assessment (EN 1804-3:2006+A1:2010; Świątek, 2020). Leg's yielding capacity is most often tested on a rammer stand by the generation of load by the hammer of the specified weight falling freely from a given height. An analytical method of yield assessment, used in Poland most often (Stoiński, 2018), enables to determine pressure changes in the leg under-the-piston space, caused by an external load of an accepted time function dependent, in general, on mining-and-geological conditions. The elastic properties of the mechanical system, constructed of a hydraulic leg and a release valve, impact the calculated pressure changes in the leg apart from the applied external load.

This publication's subject concentrates on cognitive tests oriented onto a determination exclusively of a release valve impact on pressure changes in the leg, observed during a dynamic reaction applied to the powered roof support unit from the floor. The force's time process in the leg is then characterized by a short load rising time $-t_{n}$, large load increment factor $-K_{d}$ and the average load growth rate $-w_{p, n}$. Intensive dynamic loading of such a short increase time can be obtained neither on a rammer nor on the press of a fast slide (Kalukiewicz et al., 2010). Due to that fact, the properties of a release valve were analyzed on the basis of measurements, during which a leg dynamic load was generated with the use of explosive blasting technology.

Tests of legs, subjected to dynamic loads, generated with the use of this method - for short called an explosive method - have been conducted at the present KOMAG Institute of Mining Technology since 1995. In most cases, the objective of these tests was an analysis of leg strength and the components of the hydraulic control system subject to an action of an intensive dynamic load.

Components such as the hydraulic leg, piston, and release valve can be manufactured, for example, by cutting technologies (El Bozidi et al., 2018; Peterka et al., 2008; Sentyakov et al., 2020; Elbakian et al., 2018; Saga et al, 2020). The tested components of the hydraulic control system included, among others, a few types of release valves of differentiated constructional and technical parameters.

Within this research work, some recorded time graphs of pressure in the under-the-piston space, in the aspect of operational efficiency of selected release valves, were analyzed. In this case, operational efficiency is understood as a valve reduction of parameters characterizing the time function of pressure in the leg, obtained in the result of a release valve installation.

\section{Literature review}

The hydraulic system of the powered roof support, both the legs, cylinders as well as valves and controlling components are important in the aspect of functionality and safety of a workplace and the mining process in a longwall panel (Peng, 2006; Biliński, 2005; Prusek, 2016). This problem is associated with the analysis of external load acting on the powered roof support using the theoretical models (Prusek et al., 2016; Prusek et al., 2016a; Rajwa et al., 2019; Cheng et al., 2017, Jaszczuk and Pawlikowski, 2017; Jing et al., 2017) as well as measurements taken in the longwall panel (Jasiulek et al., 2016; Jasiulek, 2019; Jasiulek, 2019a; Jasiulek et al., 2019; Szweda, 2000; Szweda, 2004). If in the surrounding rock mass there is a bump or other dynamic phenomenon, the problem of protecting, first of all, the hydraulic legs, against excessive pressure increase caused by the load to the powered roof support, is especially important (Prusek and Masny, 2015; Defu et al., 2019; Szweda, 2001; Szurgacz and Brodny, 2019; Masny, 2020). Pressure pulsation in the valve connectors caused by a dynamic load is also an important problem (Ma, W et al., 2019; El Bouzidi et al., 2018; Świątek and Stoiński, 2019, Vasko et al, 2020).

Theoretical analyses and laboratory tests of devices, protecting a hydraulic leg against overloading, concerned, among others, hydro accumulators (Domagała, 2015) and gas accumulators (Mazurek and Szweda, 2008; Mazurek, 2019). In practice, the most frequently used method of protecting a leg against damage as the result of excessive pressure increase consists of an installation of an additional release valve in the leg hydraulic system.

The protection level of a hydraulic leg against overloading is usually determined on the base of a laboratory test during which a dynamic load is acting on a leg, where a release valve is installed in its hydraulic system. A yield of a mechanical system, consisting of a leg and a hydraulic control system, is tested this way.

Tests conducted for a determination of an impact of a release valve itself on a dynamic load carried by a leg are rare. For example, Stoiński (2018) described the effect of the installation of a release valve on pressure changes in the leg. 
Spring valves with a flow rate of 400,1350 and $2000 \mathrm{dm}^{3} \cdot \mathrm{min}^{-1}$ and gas valves with a flow rate of 400 and $2500 \mathrm{dm}^{3} \cdot \mathrm{min}^{-1}$ were tested. Assessment of the effectiveness in reducing the maximum pressure as a result of the installation of the release valve was the test objective. The time process of pressure in the under-piston area of the leg without the valve and the leg with the valve installed was recorded. The dynamic load generating the pressure changes had the same energy, and identical initial conditions and the leg had the same elastic properties.

The selected technical parameters of the two-stage hydraulic leg used in tests are presented in Tab. 1.

\begin{tabular}{l|c} 
Tab. 1. The selected technical parameters of the hydraulic leg used in tests (Stoiński, 2018) \\
\hline \multicolumn{1}{c}{ Parameter } & Value \\
\hline Diameter of the $1^{\text {st }}$ stage cylinder & $320 \mathrm{~mm}$ \\
Diameter of the $2^{\text {nd }}$ stage cylinder & $250 \mathrm{~mm}$ \\
Initial yielding capacity & $2.03 \mathrm{MN}$ \\
Initial pressure & $25 \mathrm{MPa}$ \\
Working yielding capacity & $2.44 \mathrm{MN}$ \\
Nominal pressure & $30 \mathrm{MPa}$ \\
Stroke of the $1^{\text {st }}$ stage cylinder $-l_{\text {I } \max }$ & $1.375 \mathrm{~m}$ \\
Stroke of the $2^{\text {nd }}$ stage cylinder $-l_{\text {II max }}$ & $1.415 \mathrm{~m}$ \\
\hline
\end{tabular}

During all tests, the initial static pressure was $10 \mathrm{MPa}$. The valve functionality was analysed at different piston extension in $1^{\text {st }}$ stage cylinder starting from $0.9 l_{\mathrm{I} \max }=1.238 \mathrm{~m}$ to $0.1 l_{\mathrm{I} \max }=0.138 \mathrm{~m}$.

It was found that if the leg extension was about $0.9 l_{\text {I max }}$, installation of the release valve had a slight impact on reducing the maximum pressure in the under-piston area. In the case of the lower extension of the piston, the impact of the release valve was more significant. In the case of extension equal to $0.1 l_{\text {I max }}$, the tested spring release valve of nominal flowrate $2000 \mathrm{dm}^{3} \cdot \mathrm{min}^{-1}$ caused pressure reduction in the leg by $15 \%$. A similar reduction was observed using the gas valve of nominal flowrate equal to $400 \mathrm{dm}^{3} \cdot \mathrm{min}^{-1}$. Installation of the gas valve of nominal flowrate equal to $500 \mathrm{dm}^{3} \cdot \mathrm{min}^{-1}$ in the leg at an extension of the $1^{\text {st }}$ stage upper prop equal to $0.1 l_{\text {I max }}$, caused pressure reduction by $30 \%$ (Stoiński, 2018).

The time of pressure increase in the leg's under-piston area during the dynamic load test on the rammer stand ranged from 40 to $200 \mathrm{~ms}$ (Świątek, 2020; Stoiński, 2018).

The range of variability of pressure, as mentioned above, increases time covers most cases of pressure changes recorded during measurements taken in the longwall panel [Prusek and Masny, 2015; Szweda, 2001). However, load cases of a shorter increase time, even $7 \mathrm{~ms}$, were reported (Szuścik and Bomersbach, 2004). It was found that these intensive dynamic loads characterized by short load increase time and high load increment factors occur in the case when external dynamic loads acting on the powered roof support from the floor (Szweda, 2001; Prusek, 2016). The method for determining the sense of the external dynamic load to the powered support was presented by Szweda (2004).

This publication's objective is mainly an analysis of the operational efficiency of release valves in the conditions of intensive dynamic load acting on a powered roof support unit from the floor.

\section{Material and Methods}

In Poland, the adaptation of powered roof support for use in the workings threatened by rock mass bursts is determined by assessing its yielding capability. According to the procedure adopted and applied at the Central Mining Institute (Stoiński, 2018), determination of the roof support safe operation range is an important element of this assessment, using the following condition:

$$
k=\frac{F_{\max }}{F_{N}} \leq k_{S}
$$

where:

$k \quad$ - roof support loading coefficient,

$k_{s} \quad$ - leg's overload coefficient in the tests according to (EN 1804-2:2001+A1:2010),

$F_{N} \quad$ - leg's nominal load-bearing capacity,

$F_{\text {max }}$ - maximum force in the leg $f(t)$ calculated from Eq. 2.

The time process of calculated force in the leg depends both on mining and geological conditions and on roof support technical parameters. Force $f(t)$ is determined from the following relationship (Stoiński, 2018):

where:

$$
f(t)=\frac{1}{\sin \alpha} \cdot\left[F_{w}+F_{d} \cdot\left(1+k_{d} \cdot e^{-\delta t} \cdot \sin (\omega \cdot t-\varphi)\right)\right]
$$

$f(t)$ - force in the leg,

$F_{w}$ - leg's initial load-bearing capacity,

$F_{d}$ - force loading down the leg, calculated from the following formula:

$$
F_{d}=F_{r} \cdot n_{t z}-F_{w}
$$


$F_{r}$ - leg's working load-bearing capacity,

$n_{t z}$ - coefficient of loading down the working caused by rock mass burst,

$k_{d}$ - calculation coefficient,

$\alpha$ - angle of the leg inclination in relation to the base,

$\delta$ - the system's damping coefficient,

$\varphi$ - angle of the force phase shift in the leg in relation to an external load to the roof support,

$\omega$ - pulsation of the system.

Technical parameters of the roof support, including the parameters of release valve - opening pressure and flowrate, have an impact on $k_{d}, \alpha, \delta, \varphi$ and $\omega$. Determining some of the above mentioned quantities' values requires computer simulations (Rajwa et al., 2017) or laboratory tests (Świątek and Stoiński; 2019). Determination of the release valve efficiency basing on the roof support loading down coefficient $-k$ from Eq. 1 and Eq. 2 is troublesome.

The experimental evaluation of the release valve's effectiveness using the parameters of the hydraulic leg dynamic load recorded in the working (Szweda, 2001) is more advantageous solution. Based on the recorded time processes of force in the roof supports' legs, the following parameters were determined (Fig. 1):

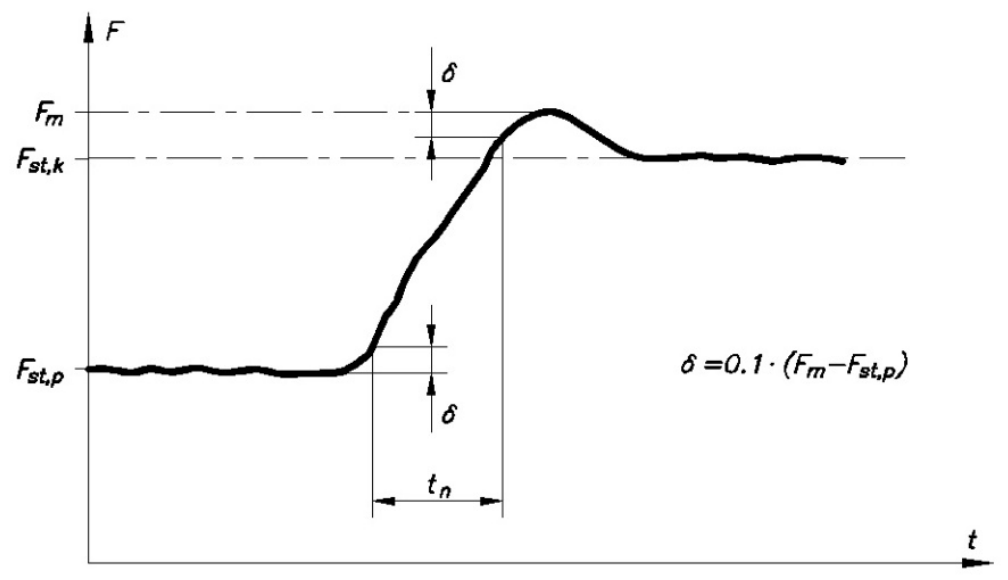

Fig. 1. Illustration of the parameters characterizing the time process of load to the leg (Szweda, 2004)

$K_{d}-$ load increase coefficient

$$
K_{d}=\frac{F_{m}}{F_{s t, p}}
$$

where:

$F_{m}$ - maximum force in legs during the discussed time process of load to the roof support,

$F_{s t, p}-$ initial static force in the legs.

Average force in in the legs $-w_{F, n}$, was determined form the following formula:

$$
w_{F, n}=\frac{0.8 \cdot\left(F_{m}-F_{s t, p}\right)}{t_{n}}
$$

where:

$t_{n}$ - time of load increase.

When determining the load increase coefficient $-K_{d}$, the maximum force in the leg $-F_{m}$ was related to the initial static force $F_{\text {st.p }}$, and not to the nominal force in the leg - $F_{N}$ (see Eq. 1), as in the working the initial static load to the legs is usually lower than the nominal load (Szweda, 2000).

\section{Parameters characterizing the efficiency of release valve}

The experimental method for assessing the release valve's effectiveness consists of determining $\mathrm{K}_{\mathrm{d}}$ and $\mathrm{w}_{\mathrm{F}, \mathrm{n}}$ in the case when identical external dynamic loads act on a hydraulic leg with a release valve installed and on the leg not equipped with such a valve.

Regardless of the used method for generating the dynamic load, the time process of pressure in the leg's under-piston area is determined - i.e., the mechanical system's response to the given external input. For this reason, the effectiveness of the release valve must be assessed using the same external load (initial conditions) and the same parameters determining the leg stiffness, such as: piston extension and the volume of the underpiston area. 
As during the test, the pressure-time process in the under-piston area is determined, it is better to calculate the average rate of pressure increase in legs $-w_{p, n}$ instead of $w_{F, n}$.

where:

$$
w_{p n}=\frac{0.8 \cdot\left(p_{m}-p_{s t, p}\right)}{t_{n}}
$$

$p_{m} \quad$ - maximum pressure in the leg's under-piston area,

$p_{s t, p}$ - initial static pressure,

$t_{n} \quad$ - time of load increase.

It has been assumed that the following parameters characterize the efficiency of the release valve operation:

- $\quad$ Relative load increase index $-\Delta K_{d}$

where:

$$
\Delta K_{d}=\frac{K_{d, b}-K_{d, z}}{K_{d, b}} \cdot 100 \%
$$

$K_{d, b}$ - load increase coefficient of the leg not equipped with a release valve,

$K_{d, z}-$ load increase coefficient of the leg with a release valve.

- Index of the relative change of load rate $-\Delta w_{p, n}$

where:

$$
\Delta w_{p n}=\frac{w_{p n, b}-w_{p n, z}}{w_{p n, b}} \cdot 100 \%
$$

$w_{p n, b}$ - average rate of load increase in the leg not equipped with a release valve,

$w_{p n, z}$ - average rate of load increase in the leg with a release valve.

The above indices characterizing the effectiveness of reducing the quantity and rate of load to the leg in the result of installing the release valve can also be used to evaluate the functionality of other devices protecting the leg against overload, e.g. gas accumulators (Mazurek, 2019).

\section{Testing methodology}

Assessment of the selected release valves' functionality under dynamic load characterized by the load increase time, load increase coefficient, and load increase rate similar to the relevant parameters recorded during floor rock bursts was the objective of the tests (Szweda, 2001; Szuścik and Bomersbach, 2004).

In Fig. 2 and Fig. 3, the test stand enabling a generation of the leg dynamic load by using explosives called an explosive method.

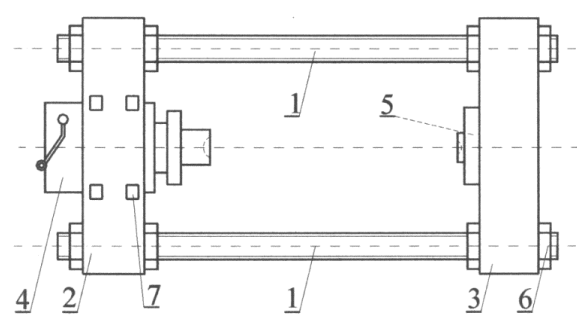

Fig. 2. Schematic diagram of the facility for testing the legs at dynamic load (Stoinski and Madejczyk, 2004)

1 - guiding screw, 2 - fixed traverse, 3 - movable traverse, 4 - generator of dynamic load, 5 - replaceable insert, 6 - nut, 7 - bolts

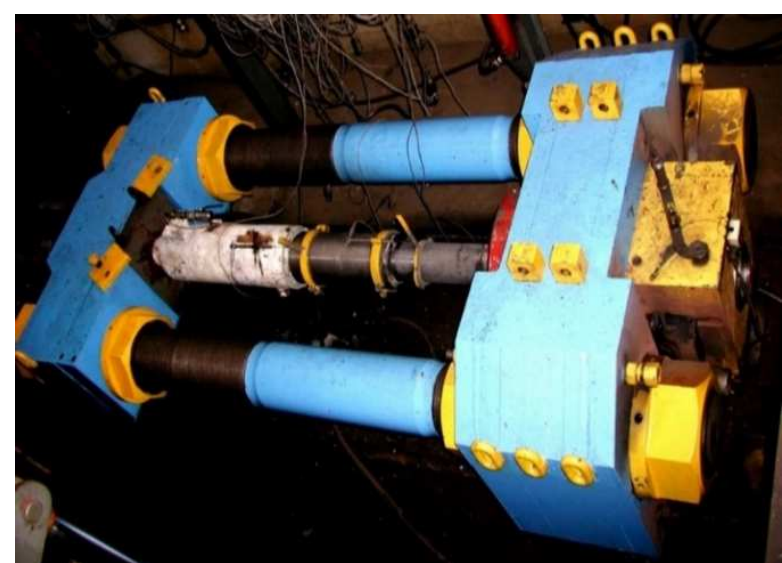

Fig. 3. Facility for testing the legs at dynamic load generated by the explosive method (Madejczyk, 2019) 
The leg's proper extension is set by shifting the movable traverse (3) with a replaceable insert (5) adapted to the legs of different geometry. The traverse (3) is locked with nuts (6). The dynamic load generator is locked by the fixed traverse (2) using bolts (7). The diagram of the dynamic load generator is shown in Fig.4.

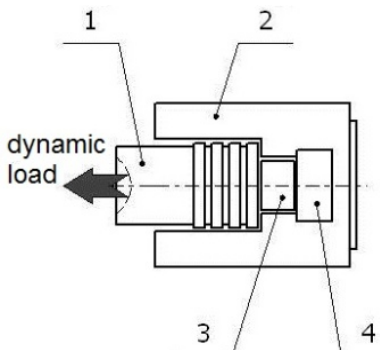

Fig. 4. Schematic diagram of the dynamic load generator (Mazurek and Szweda, 2008)

1 - piston, 2 - cylinder, 3 - explosives chamber, 4 - artillery breech lock

Piston (1) in a cylinder (2) with a chamber (3), where explosives are placed in shells, is the main component of the generator. The explosives chamber is closed with an artillery breech lock (4). Explosion in the generator's closed space is rapid, causing pressure to increase and produces propellant gaseous combustion products. The pressure of the produced gases acts on the piston (1), which loads the leg dynamically. The maximal force acting on the tested object is controlled by changing the density of the explosive in the generator's chamber. The time of pressure increase and load duration depends on explosives type and granulation (Stoiński and Madejczyk, 2004).

The maximum load to the leg generated on the test stand is $8 \mathrm{MN}$, and the maximum length of the tested leg is $4.85 \mathrm{~m}$. The weight of explosives was determined experimentally by trial tests of load to the tested object. The following 4 types of explosives were used during the tests in the KOMAG laboratory:

- $\quad \mathrm{E} 1$ - material of the smallest granulation, and thus the shortest burning time (powder),

- $\quad$ E2 - material of medium granulation and average burning time (cylinder $10 \mathrm{~mm}$ high and $9 \mathrm{~mm}$ diameter),

- $\quad$ E3 - material of medium granulation and average burning time (cylinder $10 \mathrm{~mm}$ high and diameter 9.5

$\mathrm{mm}$ ) - with lower calorific value comparing to E2 (less energy released during combustion of $1 \mathrm{~g}$ sample),

- $\quad$ E4 - material of the longest burning time.

Fig. 5 shows an example of the pressure-time process in the under-piston area of the leg $\varnothing 210 \mathrm{~mm}$ while loading it with $200 \mathrm{~g}$ of E4 type of explosives.

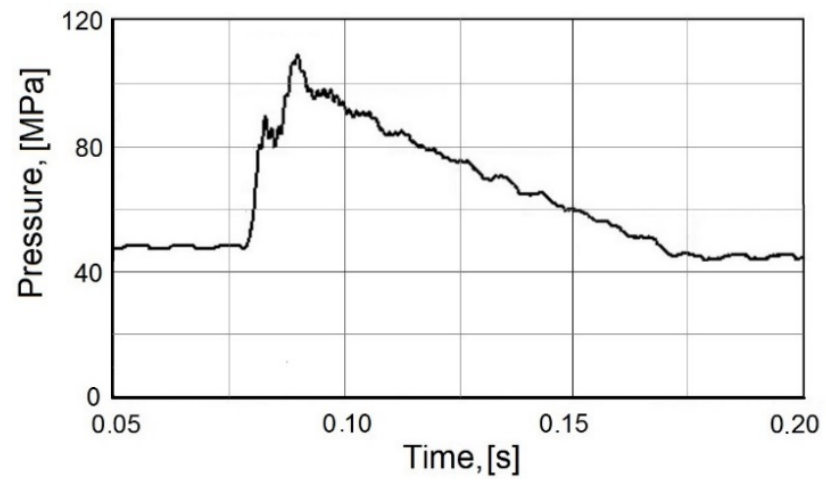

Fig. 5. Leg $\varnothing 210 \mathrm{~mm}$. Test under dynamic load using $200 \mathrm{~g}$ of $\mathrm{E} 4$ explosives

Fig. 6 shows the impact of the material weight on the maximum pressure obtained when loading the leg $\varnothing 210 \mathrm{~mm}$. The volume of the working liquid under the piston of the leg was $6.28 \mathrm{dm}^{3}$.

The repeatability of the method was determined on the basis of several hundred dynamic loads to the hydraulic legs. These measurements were performed for:

- different initial pressures in the under-piston area of the leg,

- different volumes of the under-piston area in the leg,

- different types of explosives.

The results of the tests are presented as the correlation between maximum dynamic pressure (read-out during the test) and the weight of explosives used in the test. A linear correlation between the weight of the explosives and the pressure was found. Assuming a confidence level of 90\%, it was proved that the correlation coefficient between the weight of the explosive and the pressure is significantly higher than 0.957 (Szuścik and Bomersbach, 2004). 


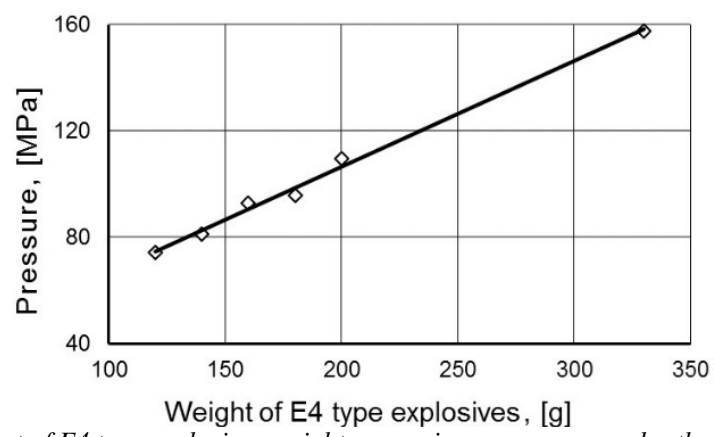

Fig. 6. Impact of E4 type explosives weight on maximum pressure under the leg's piston

Tab. 2 shows the ranges of the variability of technical parameters characterizing the dynamic load generated by the explosive method.

Tab.2. Ranges of the variability of technical parameters characterizing the dynamic load generated by the explosive method

\begin{tabular}{c|cc}
\multicolumn{3}{c}{ (Szuścik and Bomersbach, 2004). } \\
\hline Type of explosives & Time of load increase $-\mathrm{t}_{\mathrm{n}},[\mathrm{ms}]$ & Load increase coefficient $-\mathrm{K}_{\mathrm{d}}$ \\
\hline E1 & $2.6 \div 16.2$ & $1.13 \div 4.47$ \\
E2 & $3.4 \div 24.9$ & $1.17 \div 3.74$ \\
E3 & $3.1 \div 8.2$ & $1.74 \div 3.02$ \\
E4 & $4.4 \div 20.0$ & $1.23 \div 4.40$ \\
\hline
\end{tabular}

Compared to the rammer method, the explosive method generates the dynamic load with a significantly higher rate of load increase. Therefore, in the laboratory, it is possible to generate the dynamic load to the leg with similar parameters as the leg's force parameters caused by a dynamic load acting on the roof support from the floor. Tab.3 summarizes the data on the range of variability of the dynamic load parameters to the legs, recorded when the external dynamic load acted on the roof support from the floor.

Tab. 3. Parameters ranges (max., min.) and average values of loading parameters in legs, caused by dynamic load acting on the roof support from the floor (Szweda, 2001; Szuścik and Bomersbach, 2004)

\begin{tabular}{c|ccc}
\hline Parameter & Minimum & Average & Maximum \\
\hline $\mathrm{K}_{\mathrm{d}}$ & 1.19 & 1.43 & 1.83 \\
$\mathrm{t}_{\mathrm{n}}[\mathrm{ms}]$ & 7 & 33 & 99 \\
$\mathrm{w}_{\mathrm{p}, \mathrm{n}}\left[\mathrm{MPa} \cdot \mathrm{s}^{-1}\right]$ & 36.45 & 343.46 & 1072.70 \\
\hline
\end{tabular}

As during the mining operation, the cases of load to the leg of such high value of $\mathrm{K}_{\mathrm{d}}$ and $\mathrm{w}_{\mathrm{p}, \mathrm{n}}$, were recorded, testing the properties of release valves under dynamic load generated by the explosive method is justified. Tab.4.

The spring valve and two gas valves were tested. The main parameters of the tested valves are given in

Tab. 4. Main parameters of the tested valves

\begin{tabular}{|c|c|c|c|c|}
\hline \multirow[b]{2}{*}{ Valve type } & \multirow[b]{2}{*}{ Symbol } & \multirow{2}{*}{$\begin{array}{c}\text { Inlet opening } \\
\text { diameter, } \\
{[\mathrm{mm}]}\end{array}$} & \multicolumn{2}{|c|}{ Static pressure } \\
\hline & & & $\begin{array}{c}\text { Opening, } \\
{[\mathrm{MPa}]}\end{array}$ & $\begin{array}{c}\text { Closing, } \\
{[\mathrm{MPa}]}\end{array}$ \\
\hline Spring-slide with round gasket & I.410 & 16 & 45.6 & 38.9 \\
\hline \multirow{2}{*}{ Gas poppet } & $40-1$ & 40 & 48.5 & 46.5 \\
\hline & $40-2$ & 40 & 49.4 & 47.8 \\
\hline
\end{tabular}

During each test, time processes of working fluid pressure in the under-piston area of the leg, i.e. responses of the system to specific dynamic load, were recorded. To determine the impact of installed release valve on the time process of the liquid pressure in the leg, the tests of loading the leg were carried out in two stages.

At the first stage, the leg without a release valve was tested. A leg with a fixed piston extension was set to load in the test stand, generating a static load with a pressure of short increase time in the under-piston area. Then, the dynamic load was generated by igniting the specified weight of explosives in the dynamic load generator. The weight and type of the explosives were selected to obtain a pressure change in the under-piston area, characterized by a relatively high load increase coefficient $-K_{d}$.

At the second stage, the leg with the release valve was installed in the test stand, maintaining the piston extension and static pressure on the same level as at the first stage of the test. Then the time process of pressure in the leg, generated by ignition of the same explosives' weight as at the first stage of the test, was recorded.

A reduction of the dynamic load increase index, i.e. a decrease in the first pressure peak and a change in the average pressure increase rate, was the results analysis's objective. 


\section{Results}

Fig. 7 shows a comparison of the time process of pressure in the leg with a gas poppet pressure release valve of id number 40-2, with the time process of pressure in the leg in which the release valve was not installed, as well as a graph of the time process of the leg with the valve yield.

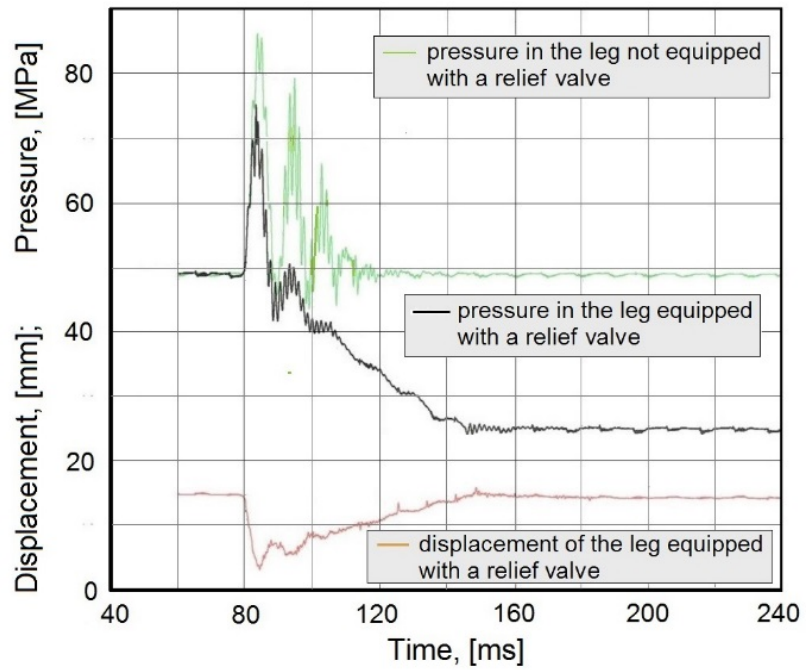

Fig. 7. Time process of pressure in the leg's working area

Changes in leg pressure and yield, as shown in Fig.7, were recorded during tests of a leg with a piston diameter $200 \mathrm{~mm}$ extended by $700 \mathrm{~mm}$. The volume of the under-piston area was $21.98 \mathrm{dm}^{3}$. In both testing stages, the leg's dynamic load was generated by the ignition of $105 \mathrm{~g}$ of E2 type explosives. Comparing to the time process of pressure in the leg without a valve, after its installation, the maximum pressure decreased from 86.4MPa to $75.4 \mathrm{MPa}$.

In the result, the dynamic load increase coefficient was reduced by approximately $15 \%$, and after the use of a release valve, it was 1.51. Dynamic pressure changes stopped at the pressure of $25 \mathrm{MPa}$, i.e. by $49 \%$ lower than the initial static pressure. In mine working conditions, such a reduction in static pressure in legs may deteriorate the roof supporting conditions. Thus it is necessary to select technical parameters of the release valve protecting the leg against overload again.

The main parameters recorded during tests of gas poppet valves are listed in Tab.5. The following indices: $\Delta K_{d}$ - changes of load increase and $-\Delta w_{p, n}$ - changes in the rate of loading to the leg, are also given in Tab. 5.

Tab. 5. Parameters recorded during tests of dynamic load to the leg equipped with gas poppet valve

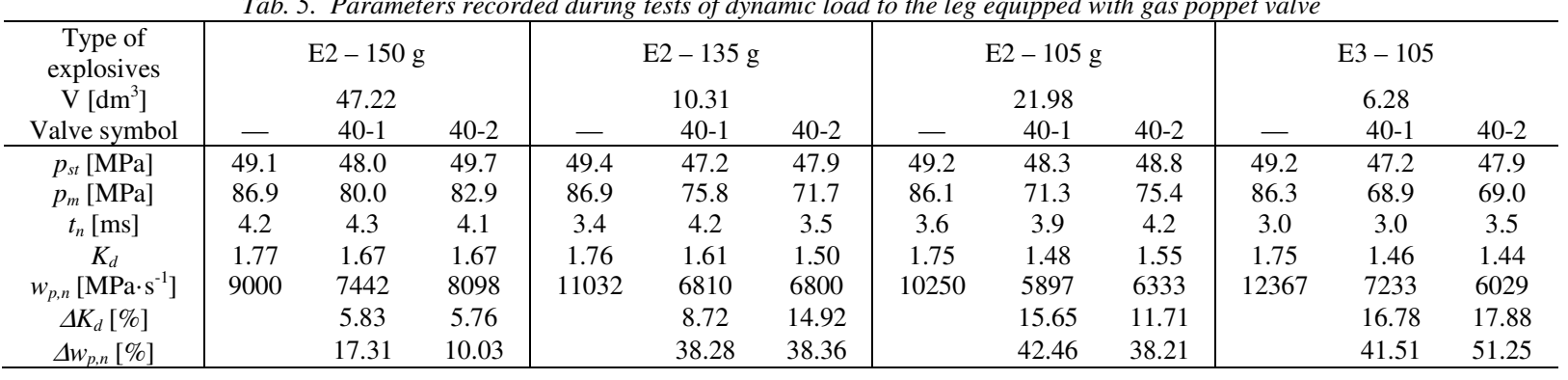

$\Delta K_{d}$ indices determined on the basis of test results of the leg with a spring valve organized according to the type, and weight of explosives and volume of the liquid in the leg's under-piston area are presented in Fig. 8.

The broken line marks the indices $-\Delta K_{d}$ obtained in the case when the initial static pressure in the leg was within the range of 24.5 to $26.5 \mathrm{MPa}$. The full line marks $\Delta K_{d}$ for which:

40.0 $\mathrm{MPa} \leq p_{s t, p} \leq 41.5 \mathrm{MPa}$.

$\Delta w_{p, n}$ determined on the base of tests with the spring valve are presented in Fig.9. The broken line shows, as in Fig.8, indices $-\Delta w_{p, n}$ which characterize pressure time processes in the leg starting from pressure $p_{s t, p}$ which meets the following condition: 


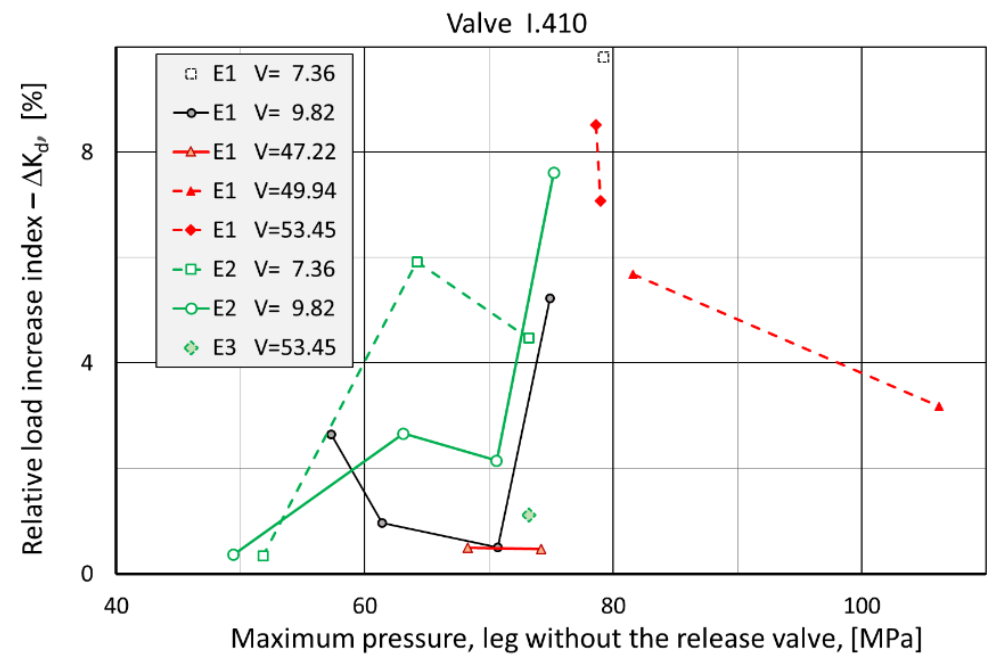

Fig. 8. $\Delta K_{d}$ indices for the leg with a spring release valve for different volumes of liquid under-piston

All the recorded $\Delta w_{p, n}$ are positive, which means that installation of the release valve in the leg's hydraulic system results in a lower rate of load to the leg. Thus, it can be assumed that the inertial force acting on the leg components is also smaller.

\section{Discussion}

The results of load tests of legs with the release valves, conducted with the use of the explosive method, confirm the required impact of the valve on the load carried by the leg. In the case of a dynamic load, of a short increase time, acting on a gas valve, the recorded index $-\Delta K_{d}-$ changes in the leg load increase are within the range $(5.76 \% ; 17.88 \%)$. As regards the spring valve, the following condition is satisfied:

$$
0.34 \% \leq \Delta \mathrm{K}_{\mathrm{d}} \leq 9.81 \% \text {. }
$$

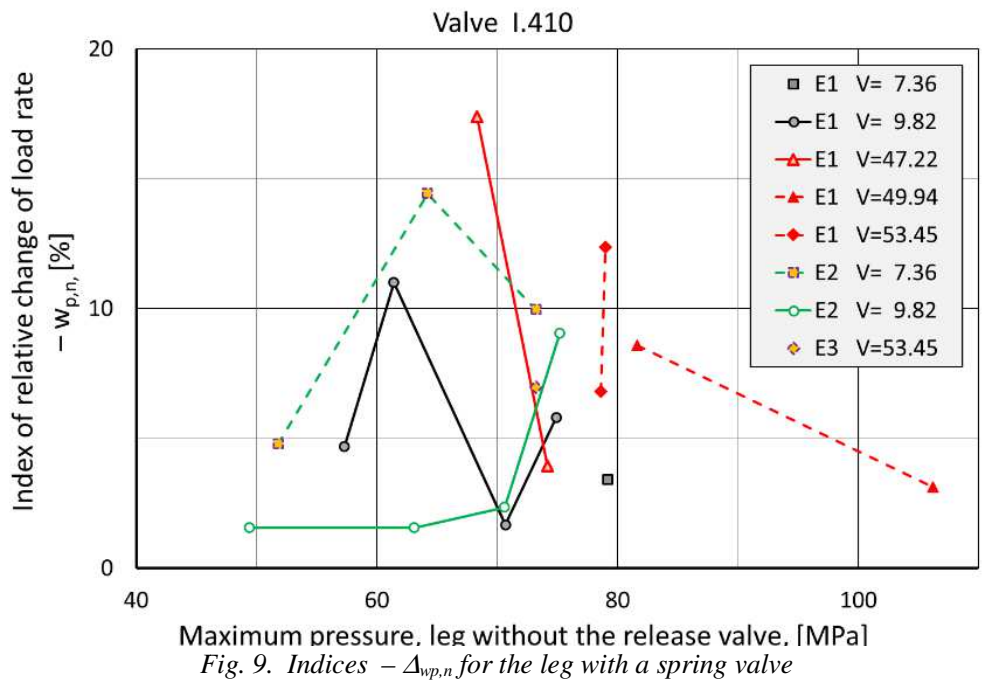

The results of testing the efficiency of spring valves on the rammer stand (Stoiński, 2018) have the following range of changeability in the load increase index:

$$
2.50 \% \leq \Delta K_{d} \leq 13.50 \% \text {. }
$$

Formally, the presented test results cannot be compared as the tested spring valves were not the same. Moreover, the tests were carried out on stands of different stiffness and with the use of different types of legs. In the rammer tests presented in (Stoiński, 2018), higher values of the $K_{d}$ were obtained (see Fig. 10) than in the tests with the use of the explosive method. However, it should be noted that the initial static pressure used in the rammer tests was $10 \mathrm{MPa}$. In the tests with the use of the explosive method, the pressure was close to the supply pressure (about $25 \mathrm{MPa}$ ) or to the nominal pressure (49MPa). 


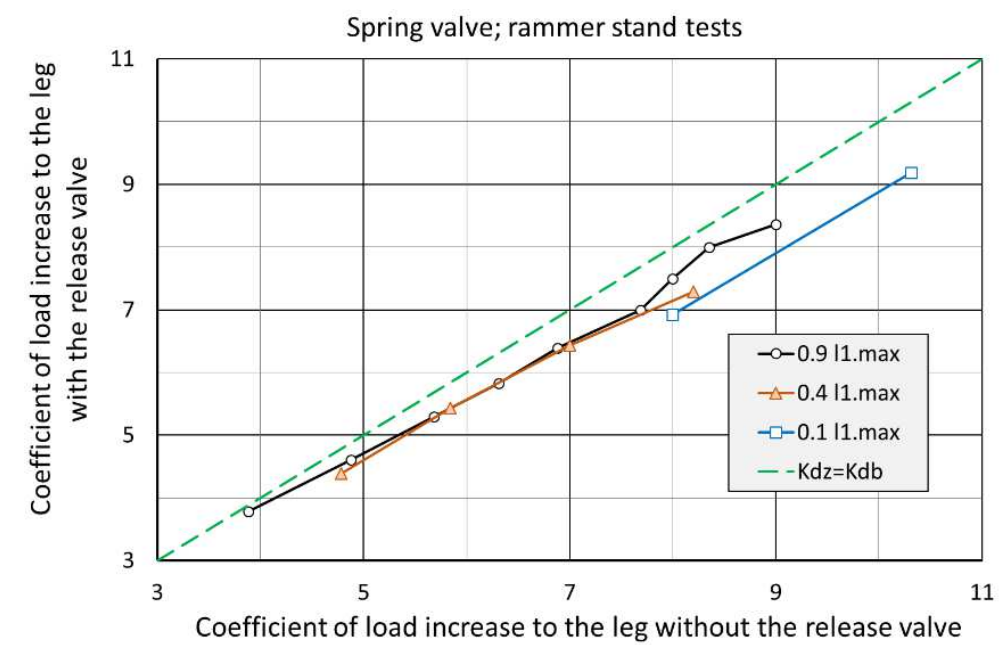

Fig. 10. Coefficients of load increase to the leg obtained in the rammer stand tests for different heights of a liquid column under the piston

The reasons mentioned above make a quantitative comparison of the discussed results unjustified. It can only be concluded that the use of a pressure release valve in the leg's hydraulic system reduces the load increase coefficient, both in the case of long and short load increase time. Fig. 11 shows the load increase coefficients of the leg with the release valve, obtained in the tests with the use of the explosive method.

Analyzing the curves presented in Fig. 10 and Fig. 11, the release valve operates in a better way in the case of higher coefficients of load increase to the leg. A similar comparison with regard to the average rate of load increase is shown in Fig. 12.

In general, the use of a release valve results in a lower rate of pressure increase in the leg as compared to $\mathrm{w}_{\mathrm{p}, \mathrm{n}}$ generated by the same external load to the leg without a release valve. The graphs presented in Fig. 12 also illustrate more favourable properties of gas valves compared to the tested spring valve. This is also confirmed by the index $-\Delta w_{p, n}$ - change in the rate of pressure increase. In the case of gas valves, it is within the following range:

$$
10.33 \% \leq \Delta \mathrm{w}_{\mathrm{p}, \mathrm{n}} \leq 51.25 \%
$$

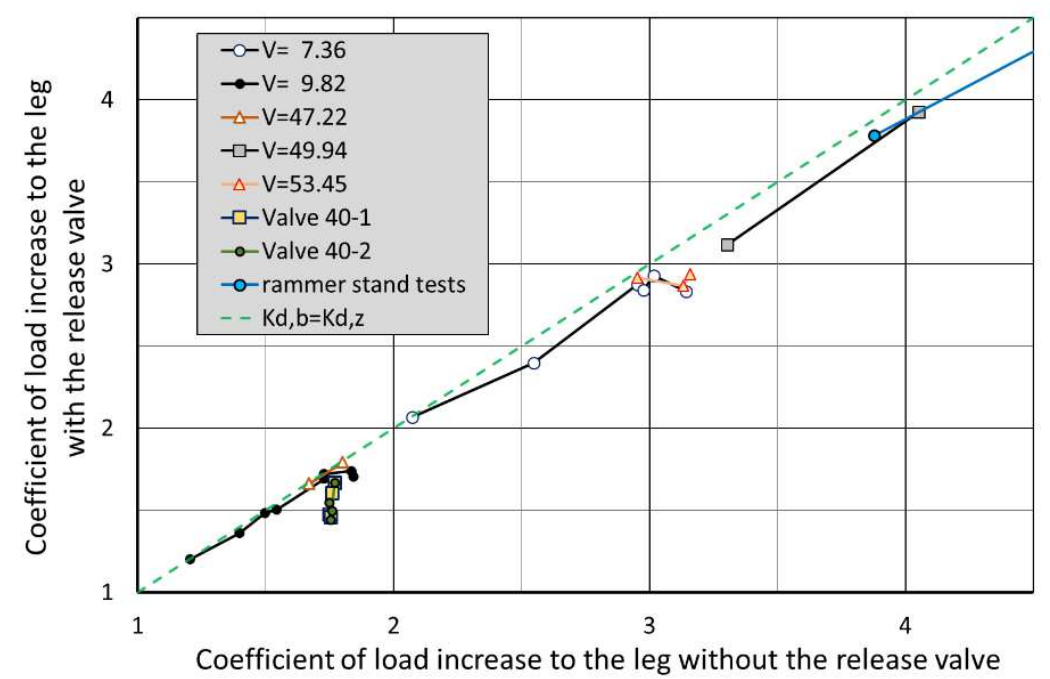

Fig. 11. Coefficients of load increase to the leg in the tests conducted by the explosion method for different volumes of liquid under the piston

In the case of the spring valve the index $-\Delta w_{p, n}$ - change in the rate of pressure increase - is within the following range:

$$
1.33 \% \leq \Delta w_{p, n} \leq 17.40 \%
$$

Reduction in the rate of pressure increase is advantageous as it results in lower dynamic forces acting on the leg components. 


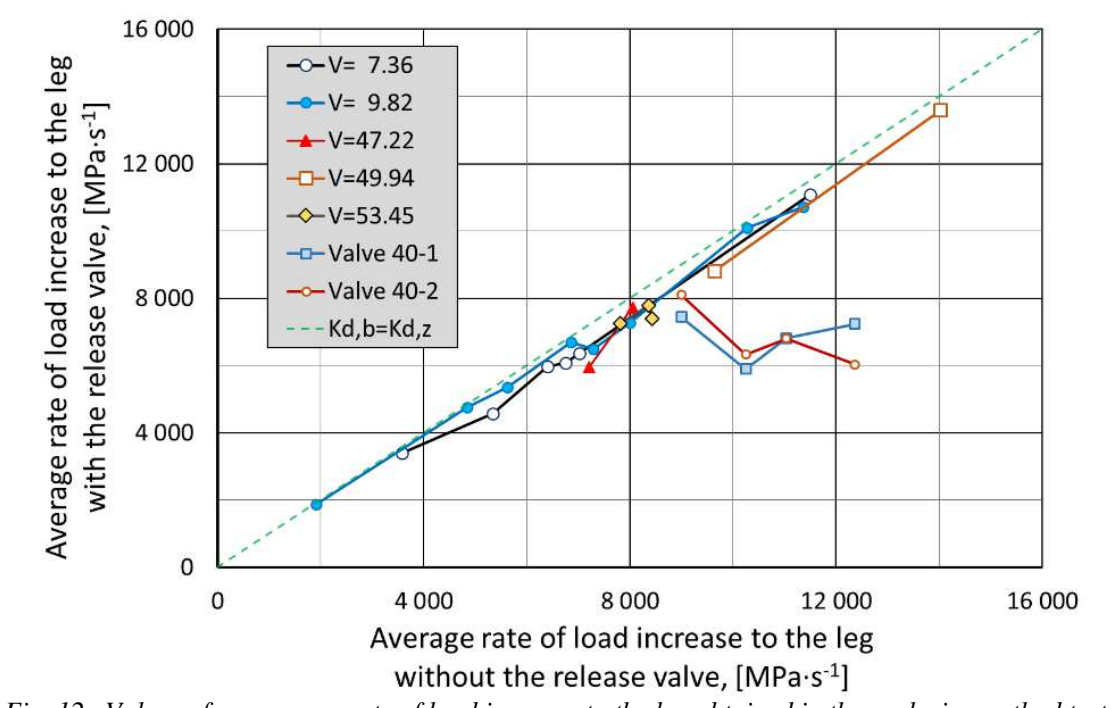

Fig. 12. Values of an average rate of load increase to the leg obtained in the explosive method tests

\section{Conclusions}

Tests of hydraulic legs under dynamic load, generated by the explosive method, confirmed the release valves' effectiveness. In the case of load, with intensive pressure increase time ranging from $2.8 \mathrm{~ms}$ to $7.6 \mathrm{~ms}$, the release valve reduces both the pressure increase coefficient and the average rate of its increase. Thus, the release valve protects the leg against excessive load, characterized by shorter load increase time than the recorded values in the case of dynamic load acting on the roof support unit from the floor.

The test results discussed in this publication confirm the necessity of precise selection of the release valve's parameters to be installed in the leg. The release valve's effectiveness, measured by the indices $-\Delta K_{d}-$ changes in load increase to the leg - is significantly influenced by the leg parameters, such as the volume of the underpiston space in the $1^{\text {st }}$ stage cylinder.

Incorrect selection of the release valve parameters may also result in incorrect cooperation of the powered roof support with the rock mass.

\section{References}

Biliński A. (2005). Metoda doboru obudowy ścianowych wyrobisk wybierkowych i chodnikowych do warunków pola eksploatacyjnego. Gliwice. Editor CMG KOMAG.

Cheng Jing-Yi, Zhang Yi-Dong, Cheng Liang, JiMing, GuWei, Gao Lin-Sheng (2017). Study of loading and running characteristic of hydraulic support in underhand mining face. Arch. Min. Sci. 62, 1, pp. $215-224$. DOI: 10.1515/amsc-2017-0016.

Defu Zhu, Shihao Tu, Hongsheng Tu, Zhenqian Yang (2019) Mechanisms of support failure and prevention measures under double-layer room mining gobs - A case study: Shigetai coal mine. International Journal of Mining Science and Technology. 29 pp. 955-962.

Domagała Z. (2015). Analiza zjawisk zachodzących w dwuteleskopowym stojaku hydraulicznym w warunkach obciążeń dynamicznych z uwzględnieniem hydroakumulatora. CYLINDER 2015 Badanie, konstrukcja, wytwarzanie i eksploatacja układów hydraulicznych. pp. 173-187. Editor ITG KOMAG Gliwice.

Elbakian A., Sentyakov B., Bozek P., Kuric I., Sentyakov K. (2018). Automated separation of basalt fiber and other earth resources by the means of acoustic vibrations. Acta Montanistica Slovaca. Vol. 23, no. 3, pp. 271-281.

El Bouzidi, S., Hassan, M., Ziada, S., (2018). Experimental characterization of the self-excited vibrations of spring-loaded valves. Journal of Fluids and Structures, Vol. 76 (January 2018) pp. 558-572.

European Standard EN 1804-3:2006+A1:2010 Machines for underground mines - Safety requirements for hydraulic powered roof supports - Part 3:Hydraulic control systems

European Standard EN 1804-2:2001+A1:2010 Machines for underground mines - Safety requirements for hydraulic powered roof supports - Part 2: Power set legs and rams.

Jasiulek D. (2019). Concept of Sensor for Mining Machines Powered by Pressure Changes. In: Świder J., Kciuk S., Trojnacki M. (eds) Mechatronics 2017 - Ideas for Industrial Applications. MECHATRONICS 2017. Advances in Intelligent Systems and Computing, vol 934. pp. 175-183, Springer. 
Jasiulek D. (2019a). Monitoring of the mining powered roof support geometry. DEStech Transactions on COMPUTER SCIENCE and ENGINEERING DOI 10.12783/dtcse/fe2019/30685 5TH International Scientific and Business Conference-Future Engineering 2019 MAY 29-30, 2019 Ołtarzew, Poland, ISBN: $\quad 978-1-60595-632-9, \quad$ ISSN: $\quad$ 2475-8841 //www.dpiproceedings.com/index.php/dtcse/issue/view/363/-showToc.

Jasiulek, D., Stankiewicz, K., Woszczynski, M. (2016). Intelligent Self-Powered Sensors in The State-Of-TheArt Control Systems of Mining Machines. Arch. Min. Sci. 61, 4, pp. 907-915. DOI 10.1515/amsc-20160060 .

Jasiulek D., Bartoszek S., Perutka K., Korshunov a., Jagoda J., Płonka M. (2019). The shield support monitoring system - operation during the support setting. Acta Montanistica Slovaka Volume 24, number 4, pp. 391401.

Jaszczuk M., Pawlikowski A. (2017). A model of equilibrium conditions of roof rock mass giving consideration to the yielding capacity of powered supports. Arch. Min. Sci. 62, 4, pp. 689-704. DOI: 10.1515/amsc2017-0049.

Jing Xuan Yang, Chang You Liu, Bin Yu (2017). The interaction between face support and surrounding rock and its rib weakening mechanism in hard coal seam. Acta Montanistica Slovaka Volume 22, number1, pp. 67-78.

Kabiesz J. (ed.) (2019). Raport roczny (2018) o stanie podstawowych zagrożeń naturalnych i technicznych w górnictwie węgla kamiennego. Katowice. Editor GIG Katowice.

Kalukiewicz A., Marianowski J., Kipczak P. (2010). Wykorzystanie prasy kuźniczej do badań stojaków obudowy zmechanizowanej o dużej podporności. KOMTECH 2010 Innowacyjne techniki i technologie dla górnictwa. Bezpieczeństwo - Efektywność - Niezawodność. pp. 405-414. Editor ITG KOMAG Gliwice.

Ma W., Ma F., Guo R. (2019). Experimental research on the dynamic instability characteristic of a pressure relief valve. Advances in mechanical engineering, Vol. 11 issue 3 pp. 1-13, DOI. $10.1177 / 1687814019833531$.

Madejczyk W. (2019). Badania stanowiskowe sekcji obudowy zmechanizowanej oraz jej elementów. Monografia No 21. Editor ITG KOMAG

Masny W. (2020). Powered support in dynamic load conditions - numerical analysis. Arch. Min. Sci. 65, 3, pp. 453-468. DOI: 10.24425/ams.2020.134129.

Mazurek K. (2019). Numerical modelling of interaction between mechanical system and fluid. IOP Conf. Ser.: Earth Environ. Sci. 261 012032; DOI:10.1088/1755-1315/261/1/012032

Mazurek K., Szweda S. (2008). Wpływ parametrów akumulatora gazowego na wielkości charakteryzujące zmianę ciśnienia w przestrzeni podtłokowej stojaka hydraulicznego. Prace naukowe - Monografia No 28. Editor CMG KOMAG Gliwice.

Peng Syd S. (2006). Longwall mining. Second edition. Morgantown, West Virginia University press

Peterka J., Pokorny P., Vaclav S. (2008). CAM strategies and surface accuracy. Annals of DAAAM for 2008 \& proceedings of the 19th international DAAAM symposium. Book Series: Annals of DAAAM and Proceedings, pp.1061-1062.

Prusek S. (2016). Stateczność wyrobisk ścianowych podczas eksploatacji pokładów węgla kamiennego z zawałem skał stropowych. Katowice. Editor GIG.

Prusek S., Masny W. (2015). Analysis of damage to underground workings and their support caused by dynamic phenomena. Journal of Mining Science, vol. 51 No. 1, pp. 63-72.

Prusek, S., Płonka, M., Walentek, A. (2016). Applying the ground reaction curve concept to the assessment of shield support performance in longwall faces. Arabian Journal of Geoscience, 9(3), 167, pp.1-15.

Prusek S., Rajwa S., Wrana A., Krzemień A (2016a). Assessment of roof fall risk in longwall coal mines. International Journal of Mining, Reclamation and Environment 31(8), pp. 558-574.

Rajwa, S., Janoszek, T., Prusek, S. (2019). Influence of canopy ratio of powered roof support on longwall working stability - A case study. International Journal of Mining Science and Technology 29(4), pp. 591598.

Rajwa S., Janoszek T., Świątek J. (2019). The simulation of fluid flow in safety elements of longwall shield support hydraulic legs. IOP Conf. Ser.: Mater. Sci. Eng 679 012017, DOI:10.1088/1757899X/679/1/012017.

Saga M., Blatnicka M., Blatnicky M., Dizo J., Gerlici J. (2020): Research of the Fatigue Life of Welded Joints of High Strength Steel S960 QL Created Using Laser and Electron Beams, Materials, Vol.13, Issue 11, Article No: 2539, DOI: 10.3390/ma13112539,

Sentyakov K., Peterka J., Smirnov V., Bozek P., Sviatski V. (2020). Modeling of Boring Mandrel Working Process with Vibration Damper. Materials Vol. 13 Issue 8, DOI: 10.3390/ma13081931.

Stoiński K. (ed.) (2018). Zmechanizowane obudowy ścianowe dla warunków zagrożenia wstrząsami górotworu. Katowice. Editor GIG Katowice. 
Stoiński K., Madejczyk W. (2004). Stojaki dwuteleskopowe z wierconymi płaszczami cylindrów. Prace naukowe - Monografia No 6. Editor CMG KOMAG Gliwice.

Szurgacz D., Brodny J. (2019). Analysis of the influence of dynamic load on the work parameters of a powered roof support's hydraulic leg. Sustainability, 11, 2570; DOI. 10.3390/su11092570, pp.1-13

Szuścik W., Bomersbach G. (2004). Symulacja obciążeń dynamicznych w stojakach hydraulicznych. Pracenaukowe - Monografie No 5. Editor CMG KOMAG Gliwice.

Szweda S. (2000) Einfluss der Setzlast auf die dynamischen Belastungen von Schreitausbau. Glückauf Forschungshefte Nr. 4 pp. 128-131.

Szweda S. (2001). Maximal loads acting on legs of powered roof support unit in longwalls with bumping hazard. Journal of Coal Science \& Engineering (China) Vol. 7 No. 2 pp. 1-15.

Szweda S. (2004). Identyfikacja parametrów charakteryzujących obciążenie sekcji obudowy zmechanizowanej spowodowane dynamicznym oddziaływaniem górotworu. Zeszyty Naukowe Politechniki Śl. s. Górnictwo z. 259. Gliwice Editor Politechnika Śląska.

Świątek J. (2020). Sposób poprawy pracy stojaka sekcji obudowy zmechanizowanej. PhD Thesis. GIG Katowice.

Świątek J., Stoiński K. (2019). Case Analysis of Damages to Control Hydraulics of the Leg in the Powered Roof Support Section. E3S Web of Conferences 105, 03013, doi.org/10.1051/e3sconf/901910503013.

Vasko, M., Saga, M., Majko, J., Vasko, A. Handrik M. (2020),: Impact Toughness of FRTP Composites Produced by 3D Printing, Materials, Vol.13, Issue 24, Article No: 5654, 